\title{
Н.Д. Орищин
}

Львівський національний медичний університет імені Данила Галицького

КНП ЛОР «Львівський обласний кардіологічний лікувально-діагностичний центр»

\section{Ехокардіографія при невідкладних станах у кардіології}

У статті проаналізовано діагностичні можливості ехокардіографії для виявлення невідкладних станів у кардіології. Докладно розглянуто шляхи ехокардіографічного пошуку при різних сценаріях критичних станів у кардіології: при гострому больовому синдромі, гострій гіпотонії та шоку, задишці, яка раптово виникла, при травмах, перипроцедурних та періопераційних ускладненнях. Описано переваги та недоліки ехокардіографічного методу в діагностиці таких невідкладних кардіологічних станів, як гострий інфаркт міокарда та його ускладнення, гостре розшарування аорти, тампонада серця, тромбоемболія легеневої артерії, систолічна дисфункція шлуночків серця, гостра клапанна патологія.

Ключові слова: невідкладні стани, ехокардіографія, задишка, шок, біль у грудях, тампонада серця, тромбоемболія легеневої артерії, розшарування аорти.

Посилання: Орищин Н.Д. Ехокардіографія при невідкладних станах у кардіології // Кардіохірургія та інтервенційна кардіологія.2021.- № 1.- C. 5-12.

To cite this article: Oryshchyn ND. Echocardiography in acute critical care in cardiology. Cardiac Surgery and Interventional Cardiology. 2021;1(32):5-12 (in Ukr.).

E хокардіографія (ЕхоКГ) при невідкладних станах у кардіологіi, поряд 3 електрокардіографією, є першочерговим знаряддям діагностики у випадках, які не стосуються гострого коронарного синдрому. Як відомо, гострий коронарний синдром з елевацією сегмента ST після виявлення змін на електрокардіограмі (ЕКГ) підлягає ургентній коронарографії і реперфузї [12]. В усіх інших випадках критичних станів у кардіології саме ЕхоКГ може дати надзвичайно важливу інформацію і повинна використовуватися в різному обсязі - від приліжкової фокусованої ЕхоКГ, яка є скороченим варіантом пошуку причини стану пацієнта, і до експертної оцінки із залученням черезстравохідного обстеження [16]. У частині випадків гострі стани в кардіології вимагають негайного хірургічного втручання наприклад, у разі тампонади серця, розшарування аорти або гострої дисфункції клапана серця. Слід розуміти, що в пацієнта в критичному стані існують певні обмеження для візуалізації - штучна вентиляція легень, яка погіршує якість зобра- ження; седація пацієнта; введення інотропних засобів, стан волеміі тощо. Водночас рішення слід прийняти швидко, і власне на результаті ехокардіографії як найдоступнішого з методів візуалізації, грунтується встановлення діагнозу та вибір методу лікування.

Згідно 3 рекомендаціями Європейської асоціації серцево-судинної візуалізації, здійснювати ЕхоКГ-обстеження при невідкладних станах повинен фахівець, який має спеціальну підготовку, брав участь у виконанні/інтерпретації не менше 150 обстежень та виконав самостійно під наглядом експерта не менше 50 обстежень у невідкладній кардіологї [16]. Однак можливий спрощений підхід, який звужує коло діагностичного пошуку в критично хворого пацієнта i полягає у визначенні стану волеміі, систолічної функції обох шлуночків та наявності рідини в серцевій сумці [18].

Невідкладні стани мають різні клінічні сценарії: це зупинка серця 3 наступною реанімацією; гострий біль у грудній клітці; задишка, 
яка виникла раптово; гіпотонія і шок; травми грудної клітки та післяпроцедурні/післяопераційні ускладнення. За патогенезом серцевих змін причини невідкладних станів у кардіології можна розділити на чотири групи: систолічна серцева недостатність (CH), СН зі збереженою скоротливістю лівого шлуночка (ЛШ), тромбоемболія легеневої артерії (ТЕЛА) та тампонада серця (табличя) [16].

\section{Зупинка серця і реанімація}

Причини зупинки серця можуть мати як кардіальне, так і несерцеве походження: це гіповолемія, тампонада серця, ТЕЛА, тяжка дисфункція лівого або правого шлуночка, напружений пневмоторакс, інфаркт міокарда (IM). Виконання реанімаційних заходів під час зупинки серця зазвичай не дозволяє виконувати діагностичні обстеження, які призводять до невиправданих затрат часу. Лише фахівці зі спеціально підготованих команд із серцево-легеневої реанімації можуть виконувати ЕхоКГ під час реанімації в перервах для контролю пульсу/ритму з метою визначення причини критичного стану [16].

\section{Гострий біль у грудній клітці}

Найчастіше причиною гострого болю в грудній клітці є гострий коронарний синдром та IM. У випадку, коли в пацієнта із затяжним нападом ангінозного болю в грудній клітці спостерігаються типові для IM зміни на ЕКГ та підвищені маркери некрозу кардіоміоцитів, виконання ЕхоКГ недоцільне. Якщо зміни на ЕКГ сумнівні або характер болю дозволяє запідозрити інший діагноз, то виконують ЕхоКГ для уточнення причини больового синдрому. Причиною різкого болю в грудній клітці, окрім гострого IM, може бути розшарування аорти або інший вид гострого аортального синдрому, стресова кардіоміопатія (синдром Такоцубо), гострий перикардит, несерцева патологія - спонтанний пневмоторакс.

ЕхоКГ може відігравати критично важливу роль у діагностиці IM, якщо клініка типова, а зміни на ЕКГ та лабораторні показники сумнівні. Порушення сегментарної скоротливості ЛШ різного ступеня (від гіпокінезії до акі- та дискінезії) є ознакою IM, i, навпаки, відсутність сегментарних розладів скоротливості на висоті больового синдрому дозволяє заперечити діагноз IM [12]. Ехокардіографія дозволяє встановити локалізацію IM та величину ураження міокарда. Повторні напади загруднинного болю під час гострого періоду IM можуть бути свідченням механічних ускладнень IM, у тому числі й розри-

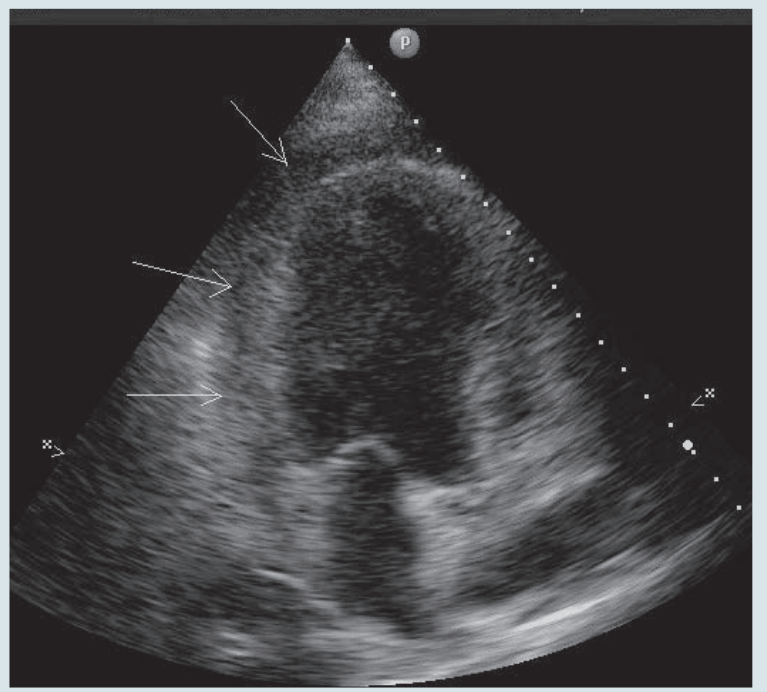

Рис. 1. Гострий інфаркт міокарда, 7-ма доба. Повторний напад болю в грудях, втрата свідомості, стійка гіпотонія. Окрім великої зони акінезії середніх сегментів та верхівки лівого шлуночка, виявлено прошарок ехогенної рідини в перикарді гемоперикард (стрілки), ознаки загрози тампонади серця

ву міокарда [6]. Гострий розрив міокарда зазвичай - це фатальне ускладнення, яке призводить до раптової смерті внаслідок тампонади серця. Однак є випадки підгострого розриву, коли кров надходить у перикардіальну порожнину поступово, або перший епізод розриву через мікротріщину в міокарді був прикритий тромботичними нашаруваннями. У пацієнта із рецидивом різкого загруднинного болю в перебігу IM свідченням підгострого розриву є накопичення рідини (крові) в перикардіальній сумці. Ця рідина (кров) зазвичай більш ехогенна, ніж звичайний перикардіальний випіт (рuс. 1). Стан потрібно диференціювати із синдромом Дреслера, який розвивається на 10-ту-21-шу добу після IM. Підгострий розрив міокарда є показанням до ургентного хірургічного втручання.

Найбільша інтенсивність болю в грудях характерна для розшарування грудної аорти. Для візуалізації грудної аорти при підозрі на розшарування використовують якнайбільшу кількість стандартних і модифікованих проєкцій, зокрема праву парастернальну, супрастернальну [8, 9, 19]. Ознакою розшарування є виявлений клапоть інтими в просвіті аорти (рис. 2). Трансторакальне ехокардіографічне обстеження має обмеження у візуалізації грудної аорти, тому при неінформативному результаті використовують черезстравохідну ЕхоКГ або інші методи візуалізації (комп'ютерну томографію, магнітно-резонансну томографію) [19]. 


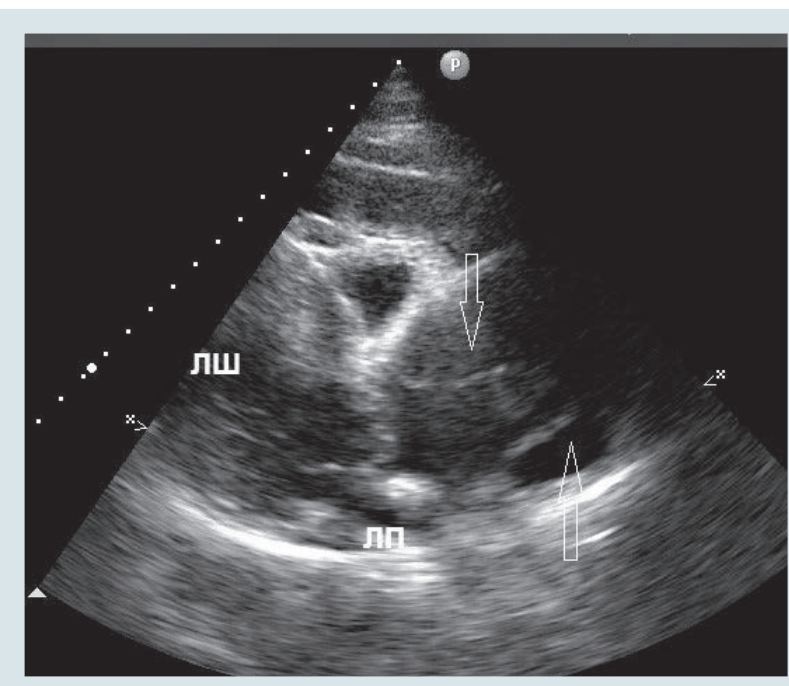

Рис. 2. Розшарування висхідної аорти. Клапті відшарованого інтимального шару в просвіті аорти (стрілки)

Інша причина гострого болю в грудній клітці - пневмоторакс. При ЕхоКГ візуалізація серця неможлива через наявність повітря у плевральній порожнині (серце «не візуалізується»).

\section{Гостра гіпотензія і шок}

Не всі причини гіпотензї мають кардіальне походження і можуть бути ідентифіковані при ЕхоКГ. Причини шокового стану можу мати серцеве і несерцеве походження: геморагічний шок (гіповолемічний), септичний (перерозподільний) шок, кардіогенний шок унаслідок серцевої патології та нейрогенний шок. Крім кардіогенного шоку, спричиненого дисфункцією лівого та/або правого шлуночка, до серцевих причин гіпотонії належать тампонада серця, масивна ТЕЛА, обструкція вихідного тракту ЛШ, компресія нижньої або верхньої порожнистої вени [13].

\section{Скорочений протокол (FOCUS) при шоку}

Скорочений варіант ЕхоКГ при гіпотонії/ шоку має такі ключові моменти: оцінка нижньої порожнистої вени, функції шлуночків серця та стану перикарда [18]. Результат такого обстеження, яке не вимагає значних затрат часу, значно звужує диференційно-діагностичне вікно: насамперед оцінюють систолічну функцію шлуночків серця і визначають, чи є причиною гіпотензії i шоку систолічна дисфункція лівого (або правого) шлуночка. Якщо функція шлуночків серця нормальна, слід оцінити волемічний стан пацієнта. Ехокардіографічно визначають стан наповнення правих відділів серця та нижньої порожнис-

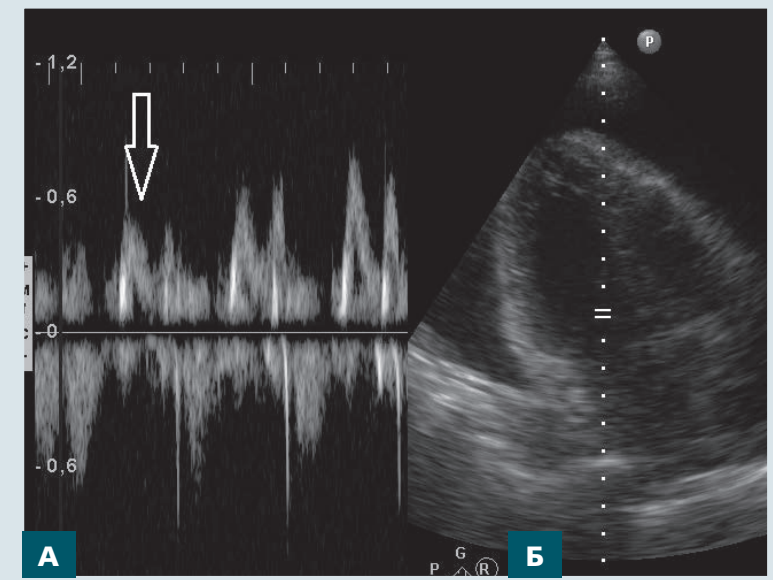

Рис. 3. Тампонада серця. Допплерографія трансмітрального потоку, зменшене наповнення лівого шлуночка на вдиху (стрілка) - ознака тампонади (А). Велика кількість рідини навколо шлуночків серця (Б)

тої вени (НПВ). Для цього використовують субкостальний доступ, за якого добре видно місце впадіння НПВ у праве передсердя, та застосовують М-спосіб. Площина сканування в М-способі повинна перетинати НПВ трохи дистальніше від місця впадіння у праве передсердя. Оцінюють діаметр НПВ та його зміни при диханні. Якщо нижня порожниста вена повністю спадається на вдиху і має діаметр менше 10 мм, то це свідчить про гіповолемічний шок. Розмір ЛШ при гіповолемічному шоку малий, скоротливість його гіперкінетична [18]. Призначені такому пацієнту інотропні препарати можуть спричинити динамічну обструкцію витоку з ЛШ і погіршити стан хворого. Лікування гіповолемічного шоку передбачає відновлення об'єму циркулюючої крові та усунення причини гіповолемії (наприклад, кровотечі). У скорочений протокол оцінки причин гіпотоніі/шоку входить оцінка наявності рідини в перикардіальній сумці: при істотній кількості рідини в перикарді з'ясовують, чи є ознаки тампонади серця. Про тампонаду серця свідчить збільшена дихальна варіабельність трансмітрального потоку, коли наповнення ЛШ на вдиху зменшується наполовину (рuс. 3). Ознаки загрози тампонади серця: діастолічне западання вільної стінки правого шлуночка та правого передсердя, маятникоподібний рух серця у великій кількості перикардіального випоту [2, 4].

\section{Експертна оцінка причини гіпотонії/шоку}

Міокардіальними причинами гіпотонії і шоку є систолічна дисфункція лівого (правого) шлуночка, зумовлена різними причинами, такими як IM, 


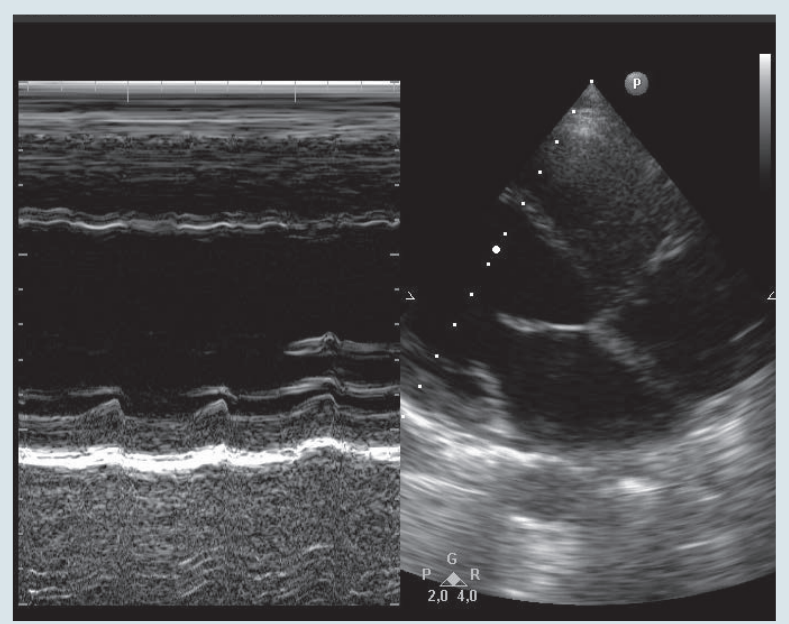

Рис. 4. Різко знижена скоротливість лівого шлуночка в пацієнтки віком 30 років із задишкою, яка гостро виникла на тлі комплексної хіміотерапії з приводу гепатиту C, фракція викиду лівого шлуночка 20 \%

гострий міокардит, кардіоміопатії. При цьому виявляють знижену скоротливість лівого (і правого) шлуночка $з$ дилатацією камери серця або без такої (puc. 4). Слід застосувати всі способи оцінки систолічної і діастолічної функції лівого і правого шлуночка [3, 10]. Особливою причиною стійкої гіпотонії при гострому IM є інфаркт правого шлуночка, тому слід звертати увагу на його скоротливість при стійкій гіпотонії в пацієнтів 3 нижнім IM [16].

Можливі так звані обструктивні причини гіпотонії і шоку. 3 боку правих відділів серця це ТЕЛА з різким перевантаженням правого шлуночка тиском (рис. 5). Ехокардіографічні ознаки перевантаження правих камер серця тиском у пацієнта з раптовим початком задишки, синкопальним станом є підставою для діагностики ТЕЛА і початку антикоагулянтної терапії [7, 14].

Причиною різкої гіпотонії і синкопальних станів може бути раніше не діагностована первинна легенева гіпертензія, особливо на тлі накладання іншої хвороби (грип, ГРЗ), що обтяжує стан пацієнта. Ехокардіографічними ознаками є значна дилатація правих камер серця, гіпертрофія стінок правого шлуночка та високий систолічний тиск у правому шлуночку, визначений за систолічним градієнтом на тристулковому клапані [11]. Причиною обструкції витоку з ЛШ є гіпертрофічна кардіоміопатія або критичний аортальний стеноз [16].

Слід оцінити наявність рідини в порожнині перикарда, у випадку перикардиту з’ясувати, чи ця кількість рідини спричинює тампонаду серця. Особливу увагу звертають на такі ознаки

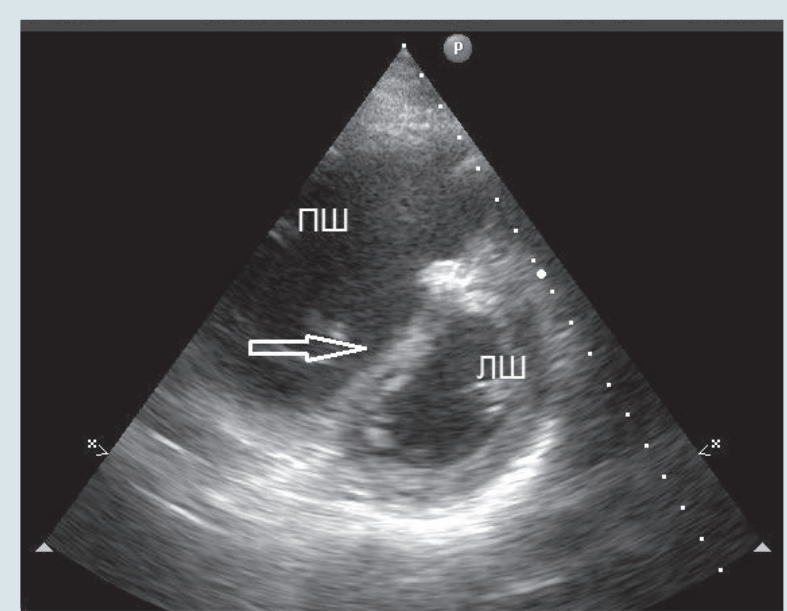

Рис. 5. Перевантаження правого шлуночка тиском при тромбоемболії легеневої артерії. Сплощення міжшлуночкової перегородки (стрілка), яке свідчить про підвищений тиск у правих відділах серця

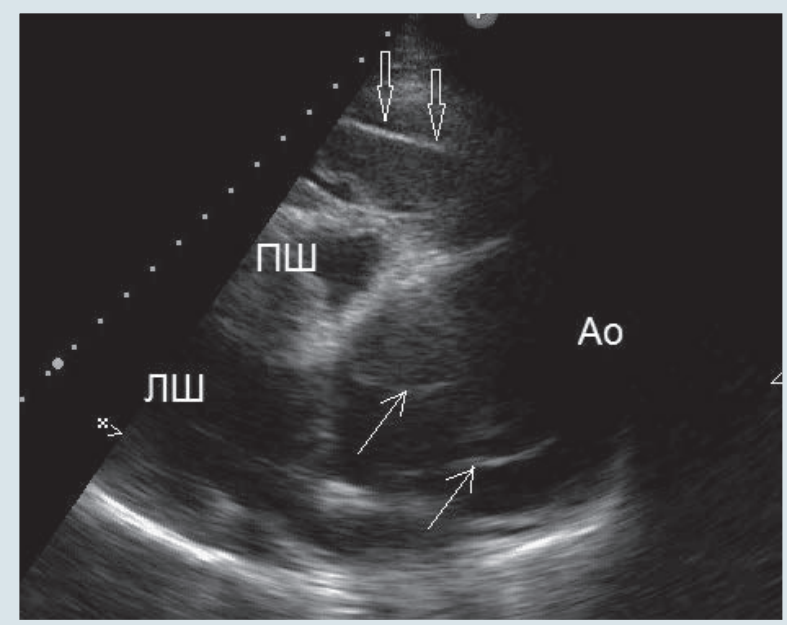

Рис. 6. Ознаки гемоперикарда та тампонади серця в пацієнта із розшаруванням висхідної аорти.

Відшарований клапоть інтими в просвіті розширеної висхідної аорти (тонкі стрілки). Значний прошарок рідини в перикардіальній сумці з ехогенними масами (згустками крові) - ознака гемоперикарда (широкі стрілки)

тампонади, як западання вільної стінки правого передсердя і правого шлуночка та на збільшену дихальну варіабельність мітрального потоку (див. puс. 3) [2, 4]. За наявності рідини в порожнині перикарда лише над правими відділами серця в пацієнта з гіпотонією/шоком слід завжди пам'ятати про таку можливу причину критичного стану з гіпотонією, як розшарування аорти (puc. 6). При цьому перикардіальний випіт містить ехогенні маси - згустки крові, що дозволяє запідозрити гемоперикард [5, 8].

Гемоперикард спричинює западання стінки правого шлуночка (ознака тампонади). Це стан найвищої хірургічної ургентності, пункція пери- 
карда в таких випадках небезпечна [19]. Подібна ситуація трапляється при IM. Випіт у порожнині перикарда в пацієнта, в якого різко знизився тиск крові на тлі попередньо стабільного перебігу IM, може бути ознакою гемоперикарда внаслідок підгострого розриву міокарда [6].

\section{Задишка, яка раптово виникла}

Причиною різкої задишки є ТЕЛА, гостра міокардіальна недостатність (набряк легень) при ішемічній та неішемічній патології міокарда, гостра дисфункція клапана (як нативного, так і протезованого), різке наростання діастолічної дисфункції ЛШ [16].

Виявлення дилатації правих відділів серця і перевантаження їх тиском у пацієнта 3 рапто-

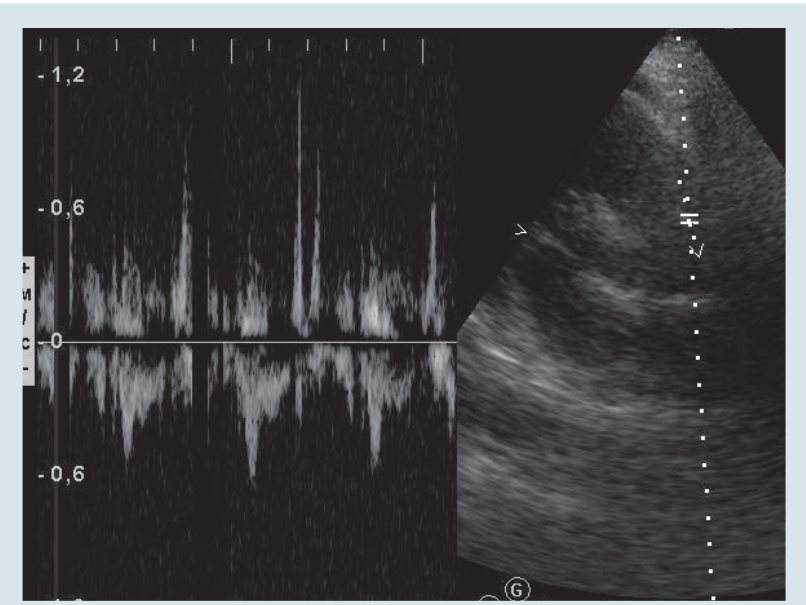

Рис. 7. Допплерографія швидкості потоку крові через легеневу артерію в пацієнта із тромбоемболією легеневої артерії. Пік потоку зміщений до початку графіка, характерний двопіковий вигляд при тромбоемболії легеневої артерії вою задишкою є підставою для діагностики i лікування ТЕЛА [7, 14]. Дилатація правих камер серця при гострій ТЕЛА може бути помірною, тому звертають увагу на співвідношення розмірів лівого і правого шлуночків та вгинання міжшлуночкової перегородки в порожнину ЛШ (див. puc. 5). Діагностичну цінність має оцінка графіку потоку крові в легеневій артерії. Значно вкорочений час прискорення швидкості потоку на легеневій артерії свідчить про швидке наростання опору в ній і є дуже специфічним показником гострої легеневої гіпертензії (рис. 7). Виявлення ЕхоКГ-показників, які свідчать про гостре перевантаження правого шлуночка тиском, у пацієнта із задишкою, яка виникла раптово, дозволяє діагностувати ТЕЛА i розпочинати специфічне лікування [14].

Причиною раптової задишки в пацієнта може бути підвищений тиск у лівому передсерді та легеневих венах унаслідок систолічної дисфункції ЛШ або гострої клапанної недостатності.

Гостра систолічна дисфункція ЛШ найчастіше є наслідком IM, рідше - гострого міокардиту, гострого токсичного впливу на міокард, або тривалого існування недіагностованої дилатаційної кардіоміопатії (див. рис. 4). Серед причин раптової появи задишки під час гострого IM на тлі рецидиву болю - розрив міжшлуночкової перегородки. Цей стан діагностують на основі виявлення систолічного турбулентного потоку 3 ЛШ у правий шлуночок при кольоровій допплерографії [6].

Тяжка гостра мітральна або аортальна недостатність є причиною задишки і набряку легень через різке підвищення тиску в лівому передсерді та легеневих венах. При гострій клапанній

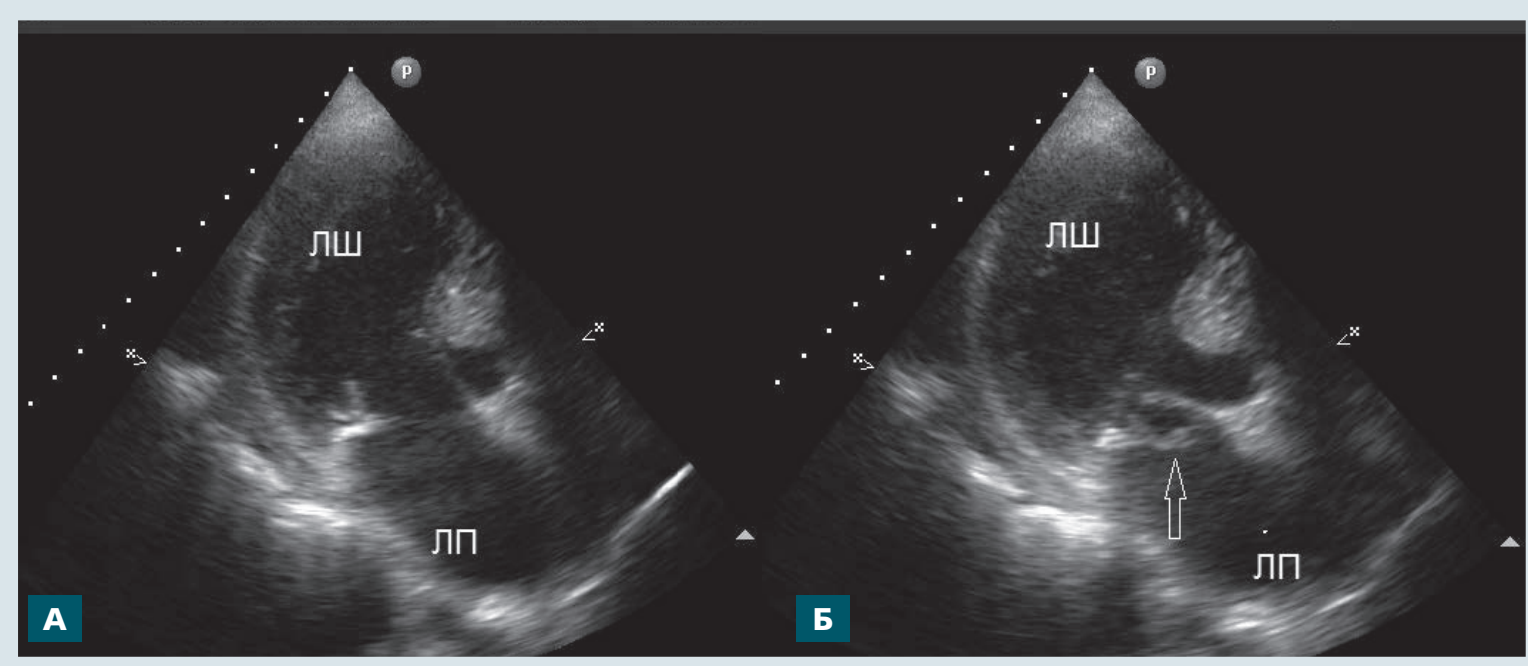

Рис. 8. Відрив хорди до задньої стулки мітрального клапана в пацієнтки з рецидивним набряком легень: А - діастола, Б - систола. Задня стулка, яка повністю пролабує в ліве передсердя під час систоли (стрілка) 


\section{Висновки}

Ехокардіографія - це основний метод приліжкової діагностики та моніторування стану пацієнта із гострою серцевою патологією. Ехокардіографія дозволяє швидко й точно оцінити морфологію серцевих структур та гемодинаміку.

Враховуючи дуже широкий перелік необхідних для ургентної серцево-судинної діагностики

\section{Конфлікту інтересів немає.}

\section{Література}

1. Бучнєва О.В. Інструментальні методи дослідження при гострих аортальних синдромах: переваги та недоліки методів // Кардіологія та кардіохірургія: безперервний професійний розвиток.- 2019.- № 2 (2).- С. 44-52. doi: 10.30702/ccs.201905.02.0094452.

2. Іванів Ю.А., Лозинська Н.В., Орищин Н.Д., Іванів І.Ю Допплерівські методи в ехокардіографічній діагностиці перикардитів // Здоров'я України.- 2013.- № 6.- С. 26-27.

3. Коваленко В.М., Ю.А. Іванів Ю.А., Долженко М.М. Кількісна ехокардіографічна оцінка порожнин серця Рекомендації робочої групи з функціональної діагностики Асоціації кардіологів України та Всеукраїнської громадської організації «Асоціація фахівців з ехокардіографії» акад. НАМН України // Новини медицини та фармації. Кардіологія.- 2011.- С. 359.

4. Коваленко В.М., Несукай О.Г. та ін. Діагностика та лікування хвороб перикарда. Рекомендації робочої групи з хвороб міокарда, перикарда, ендокарда та клапанів серця Асоціації кардіологів України // Укр. кардіол. журн.-2016.№ 2.- С. 86-95.

5. Орищин Н.Д., Іванів Ю.А. Ехокардіографічна діагностика гострого аортального синдрому // Серцево-судинна хірургія. Щорічник наукових праць асоціації серцево-судинних хірургів України.- 2008.- Вип. 16.- С. 304-306.

6. Орищин Н.Д. Ехокардіографічна діагностика механічних ускладнень інфаркту міокарда // Кардіохірургія та інтервенційна кардіологія.- 2016.- № 1.- С. 26-35.

7. Dresden S., Mitchell P., Rahimi L. et al. Right ventricular dilatation on bedside echocardiography performed by emergency physicians aids in the diagnosis of pulmonary embolism // Ann. Emerg. Med.- 2014.- Vol. 63 (1).- P. 16-24.

8. Evangelista A., Maldonado G., Gruosso D. et al. The current role of echocardiography in acute aortic syndrome // Echo Research and Practice.- 2019.- Vol. 6 (2).- P. R53-R63.

9. Evangelista A., Flachskampf F.A., Erbel R. et al. Echocardiography in aortic diseases: EAE recommendations for clinical practice // Eur. J. Echocardiogr.- 2010.- Vol. 11.P. 645-658.

10. Galderisi M., Cosyns B., Edvardsen Tr. et al. Standardization of adult transthoracic echocardiography reporting in agreement with recent chamber quantification, diastolic function, and heart valve disease recommendations: an expert consensus document of the European Association of Cardiovascular Imaging // Eur. Heart J. Cardiovasc. Imaging.- Vol. 18 (12).- P. 1301-1310. doi: 10.1093/ehjci/jex244.

11. Galie N., Humbert M, Vachier J. et al. 2015 ESC/ERS Guidelines for the diagnosis and treatment of pulmonary hypertension // Eur. Heart J.- 2016.- Vol. 37 (1).- P. 67-119. doi: 10.1093/eurheartj/ehv317.

12. Ibanez B., James S., Agewall S. et al. 2017 ESC Guidelines for the management of acute myocardial infarction in patients presenting with ST-segment elevation: The Task Force for the management of acute myocardial infarction in patients presenting with ST-segment elevation of the European Society of Cardiology (ESC) // Eur. Heart J.- 2017.- Vol. 39 (2).P. 119-177. doi: 10.1093/eurheartj/ehx393. навиків, фахівці повинні мати достатню теоретичну i практичну підготовку в невідкладній кардіологї, зокрема технічні навики виконання обстеження в особливих умовах. Початківці можуть виконувати обстеження при невідкладних станах самостійно лише при загрозливих для життя ситуаціях, коли потрібно швидко прийняти рішення, i результати такого обстеження якнайшвидше повинен переглянути фахівець експертного класу.
13. Klein T., Ramani G. Assessment and management of cardiogenic shock in the emergency department // Cardiol. Clin.2012.- Vol. 30.- P. 651-664.

14. Konstantinides S.V., Meyer G., Becattini C. et al. 2019 ESC Guidelines for the diagnosis and management of acute pulmonary embolism developed in collaboration with the European Respiratory Society (ERS): The Task Force for the diagnosis and management of acute pulmonary embolism of the European Society of Cardiology (ESC) // Eur. Heart J.2020.- Vol. 41 (4).- P. 543-603. doi: 10.1093/eurheartj/ ehz405.

15. Lancellotti P., Tribouilloy C., Hagendorff A. et al. Recommendations for the echocardiographic assessment of native valvular regurgitation: an executive summary from the European Association of Cardiovascular Imaging // Eur. Heart J.- Cardiovascular Imaging.- 2013.- Vol. 14.- P. $611-$ 644.

16. Lancellotti P., Price S., Edvardsen T. et al. The use of echocardiography in acute cardiovascular care: Recommendations of the European Association of Cardiovascular Imaging and the Acute Cardiovascular Care Association // Eur. Heart J. Acute Cardiovasc. Care.- 2015.- Vol. 4 (1).P. 3-5.

17. Lancellotti P., Pibarot P., Chambers J. et al Recommendations for the imaging assessment of prosthetic heart valves: a report from the European Association of Cardiovascular Imaging endorsed by the Chinese Society of Echocardiography, the Inter-American Society of Echocardiography, and the Brazilian Department of Cardiovascular Imaging // Eur. Heart J. Cardiovasc. Imaging.- 2016.Vol. 17 (6).- P. 589-590. doi: 10.1093/ehjci/jew025.

18. Neskovic A.N., Skinner H., Price S. et al. Focus cardiac ultrasound core curriculum and core syllabus of the European Association of Cardiovascular Imaging // Eur. Heart J. Cardiovasc. Imaging.- 2018.- Vol. 19 (5).- P. 475-481. doi: 10.1093/ehjci/jey006.

19. Nienaber C.A., Eagle K.A. Aortic Dissection: New Frontiers in Diagnosis and Management Part I: From Etiology to Diagnostic Strategies // Circulation.- 2003.- Vol. 108.P. 628 .

20. Zaidi A., Knight D.S., Augustine D.X. et al. Echocardiographic assessment of the right heart in adults: a practical guideline from the British Society of Echocardiography // Echo Res. Pract.- 2020.- Vol. 7 (1).- P. G19-G41. doi:10.1530/ERP-190051.

21. Zoghbi W., Chambers J., Dumesnil J. et al. Recommendations for evaluation of prosthetic valves with echocardiography and Doppler ultrasound // J. Am. Soc. Echocardiogr.- 2009.Vol. 22.- P. 975-1014.

22. Zoghbi W.A., Adams D., Bonow R.O. et al. Recommendations for Noninvasive Evaluation of Native Valvular Regurgitation A Report from the American Society of Echocardiography Developed in Collaboration with the Society for Cardiovascular Magnetic Resonance // J. Am. Soc. Echocardiogr.- 2017.- Vol. 30 (4).- P. 303-371. doi: 10.1016/j. echo.2017.01.007. 


\section{Н.Д. Орыщин}

Львовский национальный медицинский университет имени Данила Галицкого

КЗ ЛОС «Львовский областной клинический лечебно-диагностический кардиологический центр»

\section{Эхокардиография при неотложных состояниях в кардиологии}

В статье проанализированы диагностические возможности эхокардиографии для выявления неотложных состояний в кардиологии. Подробно рассмотрены пути эхокардиографического поиска при различных сценариях критических состояний в кардиологии: при остром болевом синдроме, острой гипотонии и шоке, одышке, которая внезапно возникла, при травмах, перипроцедурных и периоперационных осложнениях. Описаны преимущества и недостатки эхокардиографического метода в диагностике таких неотложных кардиологических состояний, как острый инфаркт миокарда и его осложнения, острое расслоение аорты, тампонада сердца, тромбоэмболия легочной артерии, систолическая дисфункция желудочков сердца, острая клапанная патология.

Ключевые слова: неотложные состояния, эхокардиография, одышка, шок, боль в груди, тампонада сердца, тромбоэмболия легочной артерии, расслоение аорты.

\section{N.D. Oryshchyn}

Danylo Halytsky Lviv National Medical University, Lviv, Ukraine Lviv Regional Clinical Medical and Diagnostic Cardiology Center, Ukraine, Lviv, Ukraine

\section{Echocardiography in acute critical care in cardiology}

Diagnostic opportunities of echocardiography in the acute cardiac care are reviewed. It is shown in detail how to perform echocardiography in different scenarios of critical conditions, especially in acute chest pain, acute hypotension and shock, in acute dyspnoea, in chest trauma, in post-procedural and post-surgical complications. The advantages and disadvantages of the echocardiographic method in acute myocardial infarction with complications, in acute aortic dissection, in cardiac tamponade, in pulmonary embolism, in systolic left ventricular dysfunction and in acute valvular dysfunction are analyzed.

Key words: critical care, echocardiography, dyspnoea, shock, chest pain, tamponade, pulmonary embolism, aortic dissection. 